\title{
PLACE-NAMING OF TOURISM DESTINATIONS IN JAWA BARAT: A TOPONYMY STUDY
}

\author{
Eva Tuckyta Sari Sujatna ${ }^{1}$, Heriyanto $^{2}$, and Kasno Pamungkas ${ }^{3}$ \\ ${ }^{1}$ Lecturer in Universitas Padjadjaran, Indonesia, eva.tuckyta@unpad.ac.id \\ ${ }^{2}$ Lecturer in Universitas Padjadjaran, Indonesia, heri.fib@gmail.com \\ ${ }^{3}$ Lecturer in Universitas Padjadjaran, Indonesia, pamungkasno@gmail.com
}

\begin{abstract}
The research on place-naming has been the focus of numerous studies. This research tries to explore the place-naming of tourism destinations in Jawa Barat. The place-naming of tourism destinations in Jawa Barat discussed in this article relates to their types and their processes morphologically. It can be shown that there are three types of place naming of tourism destination in Jawa Barat adapted from eleven Nash's classifications, the present writers found single proper noun, two (generic noun + proper noun) and three (generic noun + generic noun + proper noun) nouns, and generic noun + adjective. Besides the types adapted from Nash classifications (2015), the present writers also classify their morphological processes relating to Sujatna et al. (2016). The first process is acronym, the second is blending, the third process is coinage, the fourth process is borrowing, and the last type of process is a compounding.
\end{abstract}

Keywords: place-naming, morphological processes, Jawa Barat, acronym, blending, coinage, compounding, borrowing,

\section{INTRODUCTION}

Many researchers do their research on place-naming. The word place can be understood as something physically or mentally. Jett (1997) did his research titled "Place-Naming, Environment, and Perception among the Canyon de Chelly Navajo of Arizona", he mentioned (1997: 481) that "the great majority of Navajo place-names are translatable and literally descriptive; relatively few are commemorative, only four including personal names and none is allusive to other places or to abstract qualities. The place-names appear to have been quite stable over time". Later, Malpas (2004: 30) mentioned that

"In the work of a great many writers who aim to rehabilitate place as a central theoretical concept, place is thus distinguished from mere location through being understood as a matter of the human response to physical surroundings or locations, and, in this respect, such writers tend towards an account of place psychological terms that is not far removed from Jammer's account of the 'primitive' concept of space".

Other researcher, Shoval (2013: 612) mentioned that "Extensive research has been conducted on place 
names because they are one of the most significant markers of the intimate relationship between people and territory." Whelan (2011: 9) argued that

"While heritage and the naming of places have the potential to locate and bind people both geographically and historically, so too do they have the power to exclude. It is understood that placenaming means something, they can be translatable and literally descriptive, to be the significant markers of the intimate relationship between people and territory, or they are potential to locate and bind people both geographically and historically".

Relating to the four previous researchers, the present writers try to figure out the place-naming of tourism destinations in Jawa Barat relating to types of the place naming and the morphological processes (Sujatna, 2016).

Jawa Barat is one of the 34 provinces in Indonesia. Jawa Barat has nine cities and eighteen regencies and every city and regency in Jawa Barat has own tourism destinations.

Figure 1

Jawa Barat Tourism Map

http://www.indonesia-tourism.com/west-java/map.html

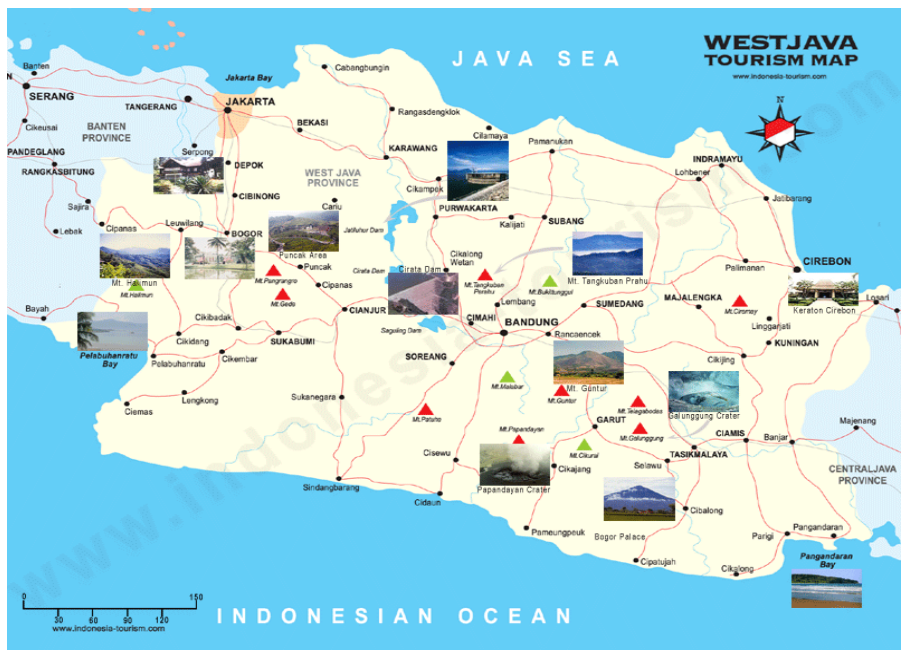

The place-naming of tourism destinations in Jawa Barat are unique, such as pantai Santolo from the words Zon Tulu (Dutch word, Cilautereun (the stop water), or Situ Patengan from the Sundanese words "pateang teangan". The variation of theplace-naming of tourism destinations are interested to be analyzed relates to their form.

The place naming of tourism destination in Jawa Barat are classified into three types: firstly, can be translatable and literally descriptive, secondly, to be the significant markers of the intimate relationship between people and territory, thirdly, are potential to locate and bind people both geographically and historically

\section{METHODS}

Using the brochures of the tourism destinations in Jawa Barat, the present writers try to collect all the placenaming of tourism destinations in Jawa Barat. Then the present writers try to classify the place-naming relating to the forms and this article analyses the place-naming of the tourism destinations in Jawa Barat. To gain an understanding of the place-naming was defined; the present writers examined the etymology of the place-naming. Around fifteen informal interviews were conducted with the local people at different points around the place, as they constitute a group that benefits directly from tourism. The interviews are in Bahasa Indonesia and Sundanese language (as the local language in Jawa Barat).

\section{THEORETICAL FRAMEWORK}

Discussing the place-naming is very close to toponymy. Toponymy is derived from Greek words tópos

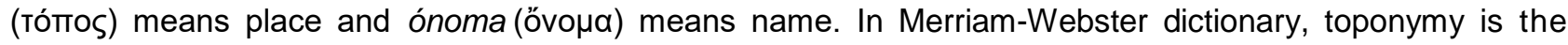
place-names of a region or language or especially the etymological study of them. 
Nash in his article Is toponymy necessary? (2015: 229) classified the Rules for English language toponymy on Norfolk Island and Kangaroo Island as followed:

1. A single English (proper) noun is productive, e.g. Cascade, Codrington, Arcadia, Possum.

2. (Proper) noun + (generic) noun (+ noun) is productive, e.g. Headstone (mono-lexemes), Pole Point, Charlotte Field, Ball Bay, Hurlstone Park (bi-lexemes), Selwyn Pine Reserve (tri-lexemes).

3. Numeral (+ noun) (+ noun) is productive (e.g. Nine Acre Piece, One Hundred Acre, 77, Four Square.

4. Adjective + noun is productive (e.g. Middlegate (monolexemes), Big House, Rocky Point, New Ground, Bloody Bridge (bilexemes)).

5. Adjective + noun + noun is productive, e.g. New Farm West.

6. Definite article + adjective (+ generic noun) is productive, e.g. The Big Flat.

7. Adjective + (generic) noun is productive, e.g. Little Cascade, Fat Gulley.

8. (Proper) noun + possessive + noun is productive, e.g. Sheres Gulley, Clitchers Corner, Burns Farm, Collins Head, Steels Point.

9. Generic noun + proper noun is productive, e.g. Mount Pitt, Lake Ayliffe.

10. Proper noun (+ proper noun) + possessive is productive, e.g. Barney Duffys, Ragseys.

11. There are fishing grounds that have arisen through humour, e.g. Oodles (where you catch oodles of fish), No Trouble Reef, No Reason, and Horse and Cart.

The classification of Nash's finding mentioned applied in analyzing the data obtained from the tourism destinations in Jawa Barat. Many different points of view can be analyzed to the data obtained as the present writers did. Sujatna, et al. (2016: 158-162) had delivered their paper in $3^{\text {rd }}$ International Conference on Education and Social Sciences and it had been published in the proceeding titled "The Morphological Processes of Jawa Barat Tourism Destination Naming" http://www.ocerint.org//intcess16 epublication/papers/204.pdf. The paper classified the morphological processed found in the data obtained from tourism destinations in Jawa Barat. The processes found are acronym, blending, borrowing, coinage, and compounding.

In this article, from the data observed, the present writers classify the data based on the Nash's findings as described in the following analysis.

\section{a. A Single (Proper) Noun}

The data obtained describe the types of place-naming. The followings are the examples of a single (proper) noun since the noun is not only proper noun but also other noun such as generic noun. The following data are a single proper noun, but they derived from different morphological processes.

(1) Pangandaran adalah Lokasi Wisata di Jawa Barat, Indonesia.

In data (1) the word Pangandaran is a noun. The noun can be generic or proper noun, since Pangandaran is a name, so it is classified into proper noun not generic noun. Based on the morphological process, the word Pangandaran, according to Sujatna et al. $(2016: 161)$ is classified into compounding. The word Pangandaran is a combination of two words, so that it can be classified into compounding since the word Pangandaran is taken from Sundanese words: pangan and daran. The Sundanese word pangan meaning in English is 'food' and the Sundanese word daran meaning in English is 'stranger'. The combination of the word Pangandaran means the source of 'food for stranger'

\section{(2) Lembang adalah sebuah kecamatan di Kabupaten Bandung Barat, Jawa Barat, Indonesia}

Data (2) describes that the word Lembang is a noun, more specific, the word Lembang is a proper noun. The morphological process of the word Lembang is not similar to the word Pangandaran. The word Pangandaran is a compounding while the word Lembang is a borrowing. The word Lembang is taken from Sundanese word ngalembang. Ngalembang meaning in English is stagnates (the water in the lake). That is why the local people called Lembang. Relating to the morphological process, that is why, the word Lembang is classified into borrowing not compounding.

\section{b. (generic) noun + (generic noun) + (Proper) noun}

The second classification is noun + noun (+ noun). The first noun is generic and the second noun is proper. 
This classification is a little bit different from the Nash's classification. In Nash's classification (2015: 229) the first noun is a proper noun while the second is a generic noun. This classification is divided into sub classification; (a) two nouns and (b) more than two nouns.

(i) Two nouns: (generic) noun + (proper) noun

(3) Nikmati keaslian Pantai Apra dengan pemandangannya yang menarik.

In data (3) the words Pantai APRA is classified into two nouns. The first noun Pantai is a generic noun while the second word, APRA, is a proper noun. According to Sujatna et al. (2016: 160) the morphological process of the word APRA an acronym. The word APRA is classified into acronym (in Bahasa Indonesia) since the letter $\mathbf{A}$ as Angkatan, $\mathbf{P}$ as Perang, $\mathbf{R}$ as Ratu, and $\mathbf{A}$ as Adil.

(4) Situ Patenggang (atau sering juga disebut Situ Patengan) merupakan sebuah danau cantik yang terletak di daerah Ciwidey, Jawa Barat.

Data (4), Situ Patengan is a noun combination of a generic noun and a proper noun. The first noun is Situ as a generic noun and the second noun Patengan as the proper noun. Relating to Sujatna et al. finding, (2016: 160) the morphological process of the word Patengan is blending. The word Patengan is taken from Sundanese words pateang - teangan. The meaning of pateang-teangan in English is looking for each other. The place describes a story of a couple, Ki Santang and Dewi Rengganis. Ki Santang left Dewi Rengganis in the village for a battle. After waiting her beloved who has not come home yet, one day, she decided to leave her village to look for him. In the same day she left her home, Ki Santang arrived and found her gone. He worried about her and tried to find her. Finally they met in their way near a lake, so that local people called the lake as Situ (=lake) Patengan (pateang-pateangan= looking for each other).

(5) Pantai Santolo merupakan salah satu tempat wisata di Garut yang cukup dikenal.

The words Pantai Santolo in data (5) is a combination of a noun and a noun. The first noun is a generic noun while the second is a proper noun. The word Santolo as, a proper noun is derived from the Dutch words.

According to Sujatna et al. (2016: 161), the words pantai Santolo is taken from Dutch words Zon and Tulu. The Dutch words, Zon (read San) Tulu meaning in English is set, so Zon Tulu means 'The Sun set'. The local people in Garut heard the pronunciation of Zon Tulu or San Tulu is Santolo not Santulu. That is why the place called Santolo. It has a borrowing process from Dutch words.

(6) Curug Cimahi merupakan salah satu tempat wisata di Bandung yang belum banyak pengunjungnya

Data (6) shows that the words Curug Cimahi are classified into a combination of two nouns. The first noun Curug is a generic noun while the second noun Cimahi is a proper noun. The word curug meaning in English is water fall. The word Cimahi is taken from Sundanese words $\mathrm{Ci}$ and mahi. Ci means water and mahi meaning in English is enough. The word Cimahi means the water is enough (for the people who live over there). So, the word Cimahi is a compounding of $\mathrm{Ci}$ and mahi.

\section{(7) Wisata Pemandian Cileungsi berlokasi tidak terlalu jauh dari Cipanas Sekarwangi.}

The words Pemandian Cileungsi is a combination of the two nouns. The first noun Pemandian is a generic noun while the second noun Cileungsi is a proper noun. Relating to the morphological process of the word Cileungsi, Sujatna et al (2016: 160) argued that the word Cileungsi is formed by a blending process. The combination of the Sundanese words culang-cileung sisi cai. Culang-cileung means looking for something, sisi means beside, and cai means water (in this context is a river), the free translation Cileungsi is looking for something beside the river. The word Cileungsi can be classified into the third type of blending; a multiple sounds from two component words are blended, while mostly preserving the sounds' order.

(ii) Three nouns: (generic) noun + (generic) noun + (proper) noun

Besides the two nouns, three nouns found in the data obtained. From the data found, the first and the second noun from the three are generic nouns while the three is a proper noun, as described in the following data.

(8) Selain akan memberikan pengalaman unik dan menarik kepada anak untuk melihat secara langsung pemandangan langit yang eksotis seperti melihat bintang-bintang, matahari, bulan dan benda-benda langit lainnya di luar angkasa melalui Teropong Bintang Bosscha.

Data (8) describes the second types of Nash's classification (2015: 229). This type is a little bit different with Nash's classification. Nash classification is (Proper) noun + (generic) noun (+ noun) while this classification is (generic) noun + (generic) noun + (proper) noun. The words Teropong Bintang Bosscha consist of three 
nouns: the first noun Teropong is a generic noun, the second noun Bintang is also generic, and the third noun Bosscha is a proper noun. According to Sujatna (2016: 161), Teropong Bintang Bosscha is a name of an observatory in Lembang, Indonesia. Bosscha is the oldest observatory in Indonesia. In 1923, the observatory was built and it was needed to study astronomy. The observatory is named after the tea plantation owner Karel Albert Rudolf Bosscha granted six hectares of his property for the new observatory. $\mathrm{He}$ is the son of the physicist Johannes Bosscha. The word Bosscha can be classified into coinage since Bosscha is a name of person.

(9) Gunung Tangkuban Perahu adalah sebuah tempat wisata yang terkenal di Lembang Bandung.

Similar to data (8), data (9) is classified into three nouns. The first (Gunung) and the second (Tangkuban) noun are generic nouns and the third is a proper noun (Perahu). Based on the morphological process, the words Tangkuban Perahu is a compounding. The word Tangkuban Perahu is a combination of two words, so that it can be classified into compounding since the word Tangkuban Perahu is taken from Sundanese words: Tangkuban and perahu. The Sundanese word tangkuban translates roughly to 'upturning' or 'upturned' while Perahu means 'boat'. So, Tangkuban Perahu in Sundanese means 'upturning boat' or 'upturned boat'. This referred to the local legend of Tangkuban Perahu creation. It relates to the story tells of "Dayang Sumbi", a beauty who lived in Jawa Barat.

\section{c. (generic) noun + adjective}

Besides the two classifications above, the following is the third classification based on the data obtained. The third is a combination of a generic noun and an adjective as describe in the following.

(10) Kawah Putih adalah sebuah tempat wisata di Jawa Barat yang terletak di kawasan Ciwidey.

The word Kawah in data (10) is a generic noun while the word Putih is an adjective. The words Kawah Putih means White Crater. Relating to the morphological process the words Kawah Putih is a compounding. The crater is called white since the color of the water crater is white. It is a sizeable highly acid lake $\mathrm{pH} 0.5-$ 1.3). It can change its color from bluish to whitish green, or brown, depending on the concentration of sulfur and the temperature or the oxidation state.

\section{CONCLUSION}

From the data analyzed it can be concluded that there are three types of place naming of tourism destination in Jawa Barat. Adapting from eleven Nash's classifications, the present writers found single proper noun, two (generic noun + proper noun) and three (generic noun + generic noun + proper noun) nouns, and generic noun + adjective. Besides the types adapted from Nash classifications (2015), the present writers also classify their morphological processes relating to Sujatna et al. (2016).

\section{REFERENCE LIST}

Bahari, Hamid. Wisata Alam Pilihan Eksotis Nusantara. Yogyakarta: Flashbooks, 2010.

Hoffer, Bates L. "Language Borrowing and Language Diffusion: An Overview." Intercultural Communication Studies, 2002: 1-37.

Jett, Stephen C. "Place-Naming, Environment, and Perception among the Canyon de Chelly Navajo of Arizona." Place-naming, Environment, and Perception, 1997: 481-493.

Katamba, Francis. Morphology. London: The Macmillan Press Ltd, 1994.

Malpas, J.E. Place and Experience. Cambridge: Cambridge University Press, 2004.

Mariena, Dewi. Analisis Strategi Pemasaran Pengelola Pantai Pangandaran Pasca Tsunami, Kabupaten Ciamis, Jawa Barat. Bogor: IPB, 2008.

Nash, Joshua. "Is toponymy necessary?" Studies in Language, 2015: 229-234.

O'Grady, William and Videa P. de Guzman. Morphology: The Analysis of Word Structure. Cambridge: Cambridge University Press, 1996.

Shoval, Noam. "Street-naming, tourism development and cultural conflict: the case of the Old City of Acre/Akko/Akka." Transactions of the Institute of British Geographers, 2013: 612 - 626. 
Spencer, Andrew. "Morphological Operations." In The Handbook of Morphology, by Andrew Spencer and Arnold M. Zwicky, 123-143. Oxford: Blackwell Publishers Ltd., 2001.

Sujatna, Eva Tuckyta Sari, Heriyanto, and Kasno Pamungkas. "Morphological Processes of Jawa Barat Tourism Destination Naming." 3rd International Conference on Education and Socal Sciences. Istanbul: www.ocerint.org/intcess16, 2016. 158 - 162.

Whelan, Yvonne. "(Inter)national Naming: Heritage, Conflict and Diaspora." ACME: An International EJournal for Critical Geographies, 2011: 7-12.

http://www.situpatenggang.com/2013/11/sejarah-situ-patenggang.html,

http://www.beachpangandaran.com/2013/07/asal-usul-pangandaran.html

http://www.nativeindonesia.com/pantai-santolo-dan-pantai-sayang-heulang-garut/

https://www.google.com/search?q=situ+patenggang+bandung\&oq=situ+patenggang\&aqs=chrome.0.69i59j6 9i57i69i60|4.3387i0j8\&sourceid=chrome\&es $\mathrm{sm}=93 \& \mathrm{ie}=U T \mathrm{TF}-8 \# \mathrm{~A}=$ =pantai+apra

https://en.wikipedia.org/wiki/Bosscha Observatory

http://www.pangandaran.org/about-pangandaran.html

http://www.gabeboni.com/2015/04/Gunung-Papandayan.html?m=1

http://www.indotravelers.com/to-go/wisata-gunung-papandayan.html 